\title{
An effective one-pot access to polynuclear dispirohetero- cyclic structures comprising pyrrolidinyloxindole and imidazothiazolotriazine moieties via a 1,3-dipolar cycloaddition strategy
}

\author{
Alexei N. Izmest'ev ${ }^{1}$, Galina A. Gazieva*1 ${ }^{* 1}$ Natalya V. Sigay ${ }^{1}$, Sergei A. Serkov ${ }^{1}$, \\ Valentina A. Karnoukhova ${ }^{*}$, Vadim V. Kachala ${ }^{1}$, Alexander S. Shashkov ${ }^{1}$, Igor E. Zanin ${ }^{3}$, \\ Angelina N. Kravchenko ${ }^{1}$ and Nina N. Makhova ${ }^{1}$
}

\section{Full Research Paper}

Address:

${ }^{1}$ N. D. Zelinsky Institute of Organic Chemistry, Russian Academy of Sciences, Leninsky Prosp., 47, Moscow 119991, Russian Federation,

${ }^{2}$ A. N. Nesmeyanov Institute of Organoelement Compounds, Russian Academy of Sciences, Vavilova Str., 28, Moscow 119991, Russian Federation and ${ }^{3}$ Voronezh State University, Universitetskaya PI., 1,

Voronezh 394000, Russian Federation

\section{Email:}

Galina A. Gazieva* - gaz@ioc.ac.ru; Valentina A. Karnoukhova* -

v_a_k_h_h@mail.ru

* Corresponding author

Keywords:

azomethine ylides; cycloaddition; diastereoselectivity; nitrogen

heterocycles; spiro compounds
Beilstein J. Org. Chem. 2016, 12, 2240-2249.

doi:10.3762/bjoc. 12.216

Received: 12 August 2016

Accepted: 06 October 2016

Published: 24 October 2016

Associate Editor: J. P. Wolfe

(c) 2016 Izmest'ev et al.; licensee Beilstein-Institut.

License and terms: see end of document.

\begin{abstract}
An effective and highly regio- and diastereoselective one-pot method for the synthesis of new polynuclear dispiroheterocyclic systems with five stereogenic centers (dispiro[imidazo[4,5-e]thiazolo[3,2-b]-1,2,4-triazine-6,3'-pyrrolidine-2', $3^{\prime \prime}$-indoles]) comprising pyrrolidinyloxindole and imidazo[4,5-e]thiazolo[3,2-b]-1,2,4-triazine moieties has been developed. The method relies on a 1,3-dipolar cycloaddition of azomethine ylides generated in situ from isatin derivatives and sarcosine to 6-benzylideneimidazo[4,5-e]thiazolo[3,2-b]-1,2,4-triazine-2,7-diones.
\end{abstract}

\section{Introduction}

A global trend in modern organic chemistry is the design of molecular systems with various degrees of complexity to maximize the incorporation of useful properties while optimizing cost and efficiency [1]. A very extended and powerful approach for constructing complex N-heterocyclic systems in a regio and stereocontrolled fashion is the 1,3-dipolar cycloaddition of azomethine ylides to electron-deficient alkenes as dipolarophiles [2-8]. The in situ preparation of azomethine ylides from different carbonyl and amino components makes the cycloaddition one of the most valuable means of combinatorial 
chemistry. Such multicomponent reactions are characterized by productivity, operational simplicity, and efficiency [9-13]. A highly interesting class of heterocycles which is accessible through 1,3-dipolar cycloaddition reactions are compounds having the spiropyrrolidinyloxindole core [14-18]. The 3,3'spiropyrrolidinyloxindole unit is found in the molecular skeleton of a large family of natural alkaloids with remarkable bioactivity profiles and interesting structural properties $[19,20]$. Derivatives with the 2,3'-spiropyrrolidinyloxindole core show various biological effects such as bactericidal and fungicidal [21], anticancer [22], cytotoxic to MCF-7 and HepG2 cells $[23,24]$, and advanced glycation end (AGE) product formation inhibitory activities [25] (Figure 1).

Over the last decade, a lot of publications have been devoted to the synthesis of dispiro compounds comprising pyrrolidine, oxindole, and other heterocycle moieties and to the evaluation of their physiological properties [24,26-32]. In this regard, our attention was directed towards hetero-annelated 1,2,4-triazines, because this motif is part of many natural and synthetic bioactive products [33-40]. The pyrimido[5,4-e]-1,2,4-triazine constitutes the core of the antibiotics fervenulin, xanthothricin, and reumycin [33,34]. Other hetero-annelated 1,2,4-triazines reveal antiviral effect against influenza A and B viruses [35], anti-HIV and anticancer [36,37], antimicrobial and antifungal activities as well as cytotoxicity to MCF-7 cells [38,39]. Based on these observations we therefore aimed at combining the spiropyrrolidinyloxindole motif with hetero-annelated 1,2,4-triazine scaffolds.
Recently, we have already combined the imidazothiazolotriazine and 3,3'-spiropyrrolidinyloxindole moieties by a 1,3dipolar cycloaddition of an azomethine ylide generated in situ from paraformaldehyde and sarcosine to oxoindolylidene derivatives of imidazothiazolotriazine. During this work we have found that the "small" azomethine ylide generated from paraformaldehyde and sarcosine approaches the double bond plane in (oxoindolylidene)imidazothiazolotriazines mainly from the side of the imidazolidine ring opposite to the phenyl groups (syn attack) (Scheme 1) [5].

To further expand the spectrum of biological activity, it is of interest to synthesize the other types of spiro compounds such as the 2,3'-spiropyrrolidinyloxindole structure which is isosteric with the 3,3 '-spiropyrrolidinyloxindole and to study the diastereoselectivity of its formation. It could be expected that the cycloaddition of more bulky azomethine ylides generated from isatins and sarcosine to benzylidene derivatives of the same imidazothiazolotriazine will proceed from the less sterically hindered side [41] (anti attack).

Herein, we report a regio- and diastereoselective one-pot method for the synthesis of a novel class of polynuclear dispiroheterocyclic structures comprising 2,3'-spiropyrrolidinyloxindole and imidazo[4,5-e]thiazolo[3,2-b]-1,2,4-triazine moieties. The synthesis is based on a 1,3-dipolar cycloaddition of azomethine ylides generated in situ from isatins and sarcosine to tailor-made 6-benzylideneimidazo[4,5-e]thiazolo[3,2-b]-1,2,4triazine-2,7-diones.<smiles>[R]OC(=O)C1C[C@@H]2Cc3ccccc3CN2[C@]12C(=O)Nc1ccc([R])cc12</smiles><smiles>[R]OCC1=C([PH])[C@@]2(CN3Cc4ccccc4C[C@@H]32)C(=O)Nc2ccc([R])cc21</smiles>

$\mathrm{R}=\mathrm{H}, \mathrm{Br}$

bactericidal and fungicidal<smiles>CCOC(=O)C1=C(C(=O)OCC)[C@]2(C(=O)OCC)NC1(C(=O)OCC)C(=O)Nc1ccccc12</smiles>

cytotoxic to MCF-7 and HepG2 cells<smiles>O=C(c1ccccc1)C1C([C@H](c2ccccc2)c2ccc(OCCN3CCCC3)cc2)C2(C(=O)Nc3ccc(Cl)cc32)N2C(c3ccccc3)SC[C@H]12</smiles>

anticancer<smiles>O=C1Nc2ccccc2[C@@]12C(=O)[C@@H](c1ccccc1)[C@H](c1ccccc1)[C@H]2c1ccccc1</smiles>

AGE product formation inhibitor 


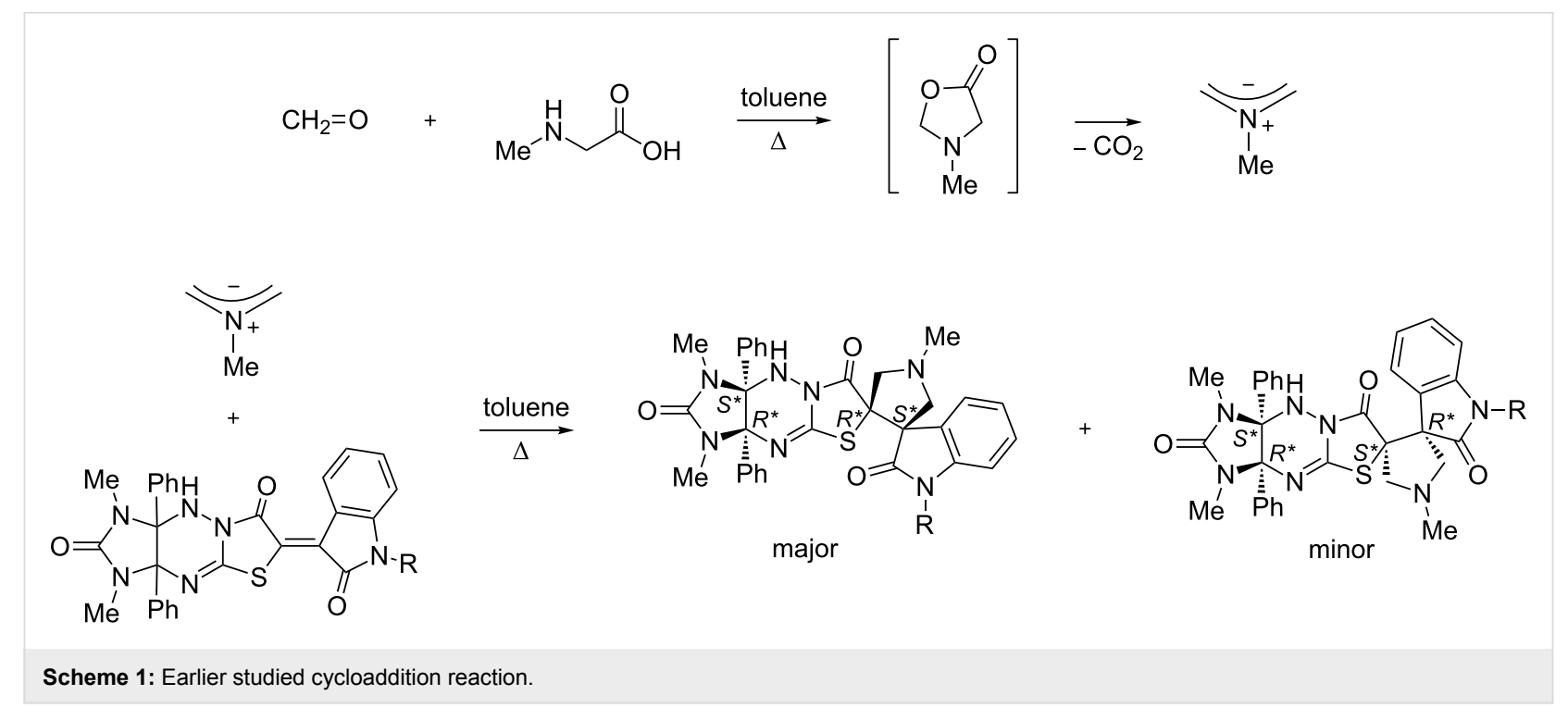

\section{Results and Discussion}

The required dipolarophiles $\mathbf{1 a}-\mathbf{c}$ were prepared by the threecomponent condensation of imidazotriazinethione $\mathbf{2}$, bromoacetic acid, and aromatic aldehydes (Scheme 2), as was described earlier by us [41]. The starting compound $\mathbf{2}$ is readily accessible and can be synthesized from 4,5-dihydroxy-4,5diphenylimidazolidine-2-one [42] and thiosemicarbazide in $96 \%$ yield [43].

To optimize the 1,3-dipolar cycloaddition reaction conditions, 4-bromobenzylidene derivative 1a was chosen as a model substrate in the reaction with sarcosine and isatin 3a. The solvent, reaction time, and temperature were varied (Table 1).

As can be seen from Table 1, the cycloaddition was carried out in different solvents such as ethanol, chloroform, acetonitrile, and toluene. When the reaction was performed in ethanol or toluene, product 4a was obtained in only low yields (Table 1, entries 1-3). Slightly increased yields were achieved in refluxing chloroform (Table 1, entries 4 and 5) and the best results were obtained in refluxing acetonitrile (Table 1, entries 6-9). At room temperature, the reaction does not proceed at all (Table 1, entry 10). Changing the reaction time from $24 \mathrm{~h}$ to $30 \mathrm{~h}$ significantly improved the yield of product $4 \mathbf{a}$ whereas a further increase of the reaction time $(>36 \mathrm{~h})$ did not further improve the yield (Table 1, entries 6-9). The reaction progress was monitored by recording ${ }^{1} \mathrm{H}$ NMR spectra of samples taken from the reaction mixture after $24,30,36$, and $42 \mathrm{~h}$. The formation of the pyrrolidine ring was detected by the appearance of triplets for the ring $\mathrm{CH}_{2}$ and $\mathrm{CH}$ group protons at 3.56, 3.95, and $4.45 \mathrm{ppm}$. Doublets for the C-3a and C-9a phenyl orthoprotons in compound $4 \mathrm{a}$ (6.13 and $6.55 \mathrm{ppm}$, respectively) were observed at higher field than those of compound 1a (6.75 and $6.83 \mathrm{ppm}$ ). The integrated intensity ratio of these protons was used to calculate the ratio of the target and starting compounds.

With the optimized conditions in hand, we next investigated the substrate scope for the reaction. First, various isatins $\mathbf{3 a}-\mathbf{e}$ were used for the generation of the azomethine ylides for the cycloaddition with compound 1a (Scheme 3, Figure 2).

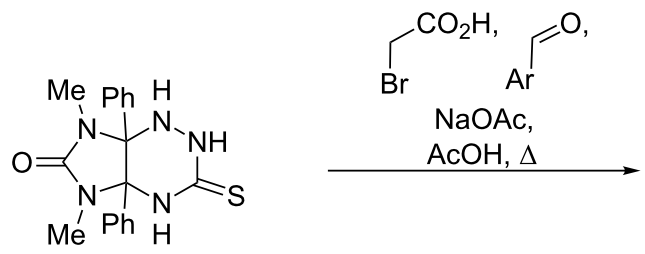

2

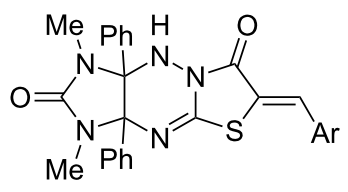

$1 a-c(44-56 \%)$

$\mathrm{Ar}=4-\mathrm{BrC}_{6} \mathrm{H}_{4}(\mathbf{a}), 4-\mathrm{O}_{2} \mathrm{NC}_{6} \mathrm{H}_{4}(\mathbf{b}), \mathrm{Ph}(\mathbf{c})$ 
Table 1: Optimization of the 1,3-dipolar cycloaddition reaction conditions. $^{\mathrm{a}}$<smiles>CN1C(=O)N(C)C2(c3ccccc3)Nn3c(s/c(=C\c4ccc(Br)cc4)c3=O)=NC12c1ccccc1</smiles><smiles>O=C1Nc2ccccc2C1=O</smiles><smiles>CCCCCCC</smiles>

$3 a$

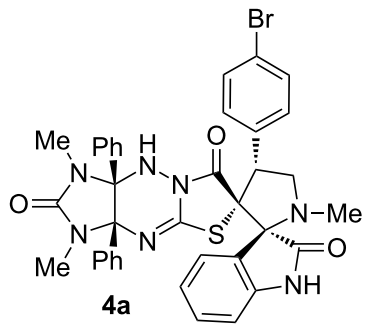<smiles>CNCC(=O)O</smiles>

\begin{tabular}{|c|c|c|c|c|}
\hline Entry & Solvent & Temp. $\left({ }^{\circ} \mathrm{C}\right)$ & Time (h) & Yield $(\%)^{b}$ \\
\hline 1 & $\mathrm{EtOH}$ & reflux & 24 & 20 \\
\hline 2 & $\mathrm{EtOH}$ & reflux & 42 & 23 \\
\hline 3 & toluene & reflux & 24 & 15 \\
\hline 4 & $\mathrm{CHCl}_{3}$ & reflux & 24 & 50 \\
\hline 5 & $\mathrm{CHCl}_{3}$ & reflux & 42 & 59 \\
\hline 6 & $\mathrm{MeCN}$ & reflux & 24 & 56 \\
\hline 7 & $\mathrm{MeCN}$ & reflux & 30 & 71 \\
\hline 8 & $\mathrm{MeCN}$ & reflux & 36 & 78 \\
\hline 9 & $\mathrm{MeCN}$ & reflux & 42 & 79 \\
\hline 10 & $\mathrm{MeCN}$ & $\mathrm{rt}$ & 42 & 0 \\
\hline
\end{tabular}

aReaction conditions: heating the mixture of compound $1 \mathrm{a}(0.5 \mathrm{mmol})$, isatin (3a, $0.5 \mathrm{mmol})$, and sarcosine $(0.5 \mathrm{mmol})$ in the corresponding solvent $(40 \mathrm{~mL})$ for the indicated time. 'Isolated yield.
It was found that apart from model substrate 3a, $N$-alkyl- (3b,c), $N$-allyl- (3d) and $N$-methyl-5-bromoisatins (3e) reacted with sarcosine and dipolarophile 1a to afford the desired products 4a-e in $54-78 \%$ yields. Next, the nitrobenzylidene and benzylidene derivatives $\mathbf{1 b}, \mathbf{c}$ were subjected to the reaction with isatins $\mathbf{3 a}-\mathbf{e}$ and sarcosine under the optimized conditions to afford the dispiro compounds $\mathbf{4 f -}-\mathbf{0}$ in $52-83 \%$ yields. As shown in Figure 2, the best yields of the cycloadducts 4 were observed in the reaction of unsubstituted isatin (3a) as the carbonyl component for the generation of the azomethine ylide as well as for nitrobenzylidene derivative $\mathbf{1 b}$ as dipolarophile.

To further extend the substrate scope of this reaction, we used benzylidene derivatives of other imidazothiazolotriazines $1 \mathbf{1}-\mathbf{f}$ without substituents at the bridge carbon atoms $\mathrm{C}(3 \mathrm{a})$ and $\mathrm{C}(9 \mathrm{a})$. The previously unknown compounds $\mathbf{1 d - f}$ were synthesized in good yields by the condensation of imidazothiazolotriazines 5a,b [44] with the corresponding aromatic aldehydes (Scheme 4).

These derivatives cannot be prepared by a three-component condensation of imidazotriazinethione with bromoacetic acid and an aromatic aldehyde, similarly to the synthesis of compounds 1a-c. The reaction of aromatic aldehydes with imidazotriazinethiones without phenyl substituents in acidic media results in hydrazone formation and triazine-ring contraction [45].

The reaction of compounds $\mathbf{1 d}-\mathbf{f}$ with sarcosine and isatins 3a,d,f also proceeded successfully, but required the addition of chloroform to the reaction mixture and an increased reaction time of $72 \mathrm{~h}$. The novel dispiro compounds $\mathbf{4 p - t}$ were finally obtained in $55-74 \%$ yields (Figure 3 ).<smiles>[R]c1ccc2c(c1)C(=O)C(=O)N2[R1]</smiles><smiles>[R]c1ccc2c(c1)C(=[N+](C)C)C(=O)N2[R]</smiles><smiles>CN1C(=O)N(C)C2(c3ccccc3)Nn3c(s/c(=C\[Al])c3=O)=NC12c1ccccc1</smiles>

1a-c

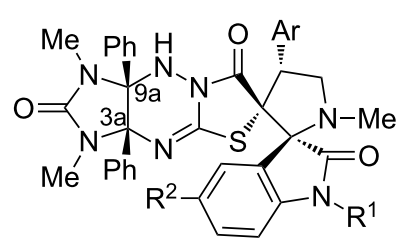

4a-o

3: $R^{2}=H, R^{1}=H(a), M e(b), E t(c)$, Allyl (d), $R^{2}=B r, R^{1}=M e(e)$ 


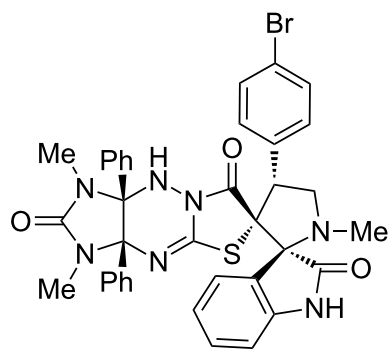

$4 a, 78 \%$

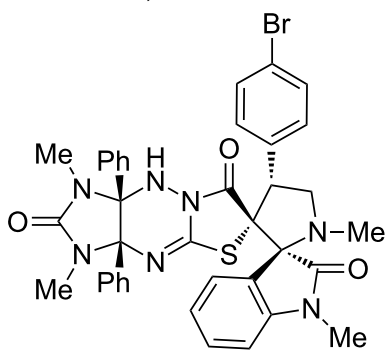

4b, $69 \%$

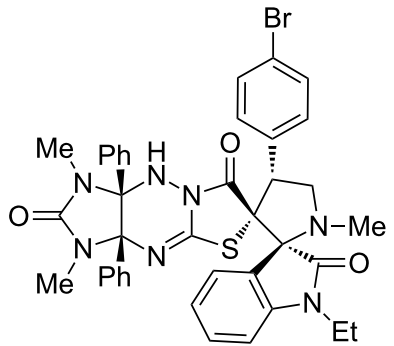

4c, $54 \%$

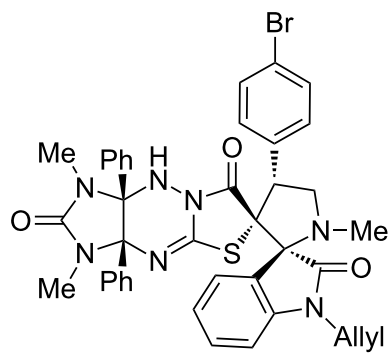

4d, $66 \%$

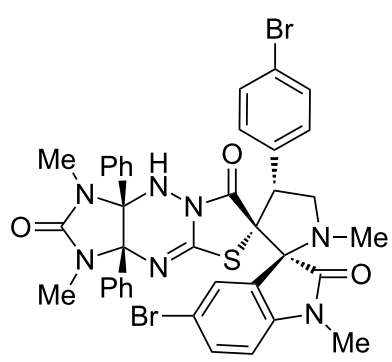

4 e, $55 \%$

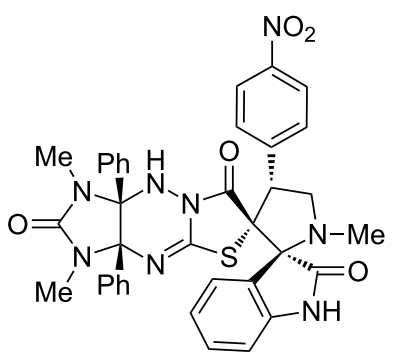

4f, $83 \%$

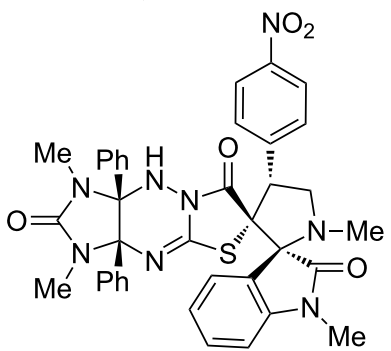

4g, $73 \%$

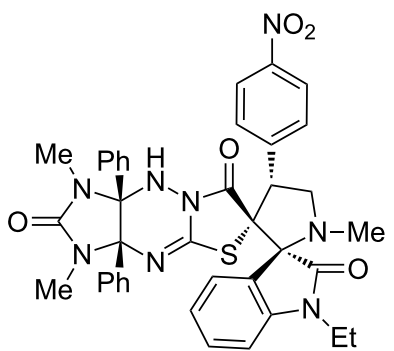

$4 h, 58 \%$

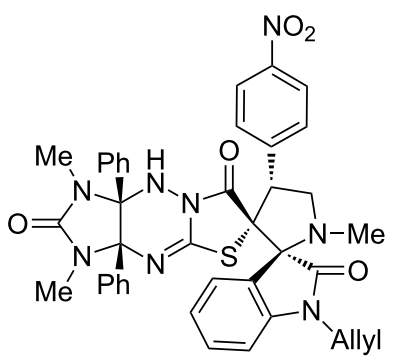

$4 i, 75 \%$

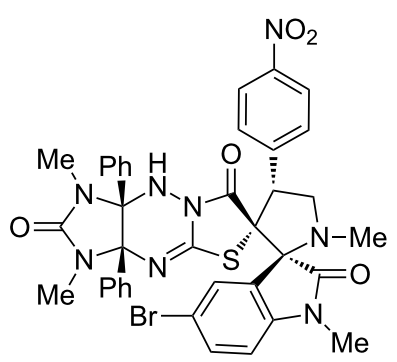

4j, $71 \%$

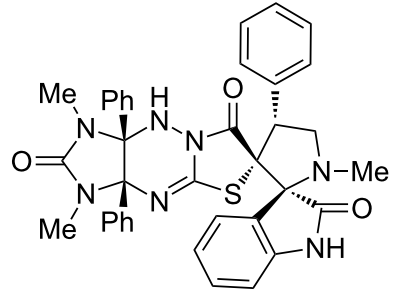

4k, $73 \%$

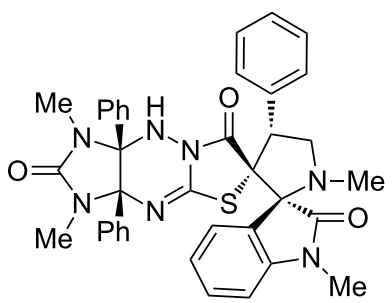

4I, $72 \%$

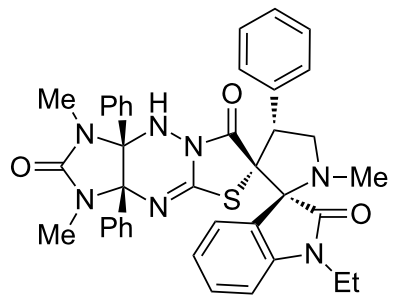

$4 \mathrm{~m}, 59 \%$

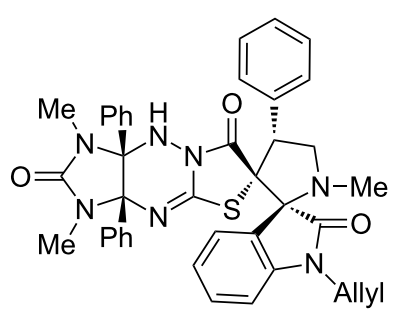

$4 n, 62 \%$

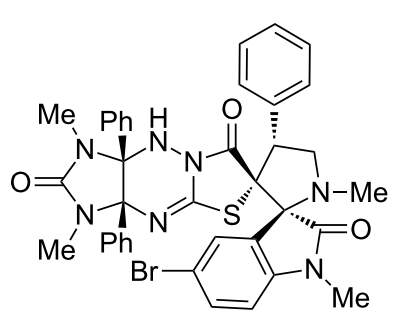

40, $52 \%$

Figure 2: Synthesis of dispiro compounds $4 \mathrm{a}-\mathbf{0}$. Reaction conditions: heating the mixture of compounds 1 ( $0.5 \mathrm{mmol})$, isatins 3 ( $0.5 \mathrm{mmol})$, and sarcosine $(0.5 \mathrm{mmol})$ in acetonitrile $(40 \mathrm{~mL})$ for $36 \mathrm{~h}$. 
㧒

$5 a, b$

$5 a, R=M e$

5b, $R=E t$<smiles>[R]N1C(=O)N([R])C2Nn3c(s/c(=C\[Al])c3=O)=NC21</smiles>

1d-f (53-70\%)

1d, $\mathrm{R}=\mathrm{Me}, \mathrm{Ar}=4-\mathrm{O}_{2} \mathrm{NC}_{6} \mathrm{H}_{4}$

1e, $\mathrm{R}=\mathrm{Et}, \mathrm{Ar}=4-\mathrm{O}_{2} \mathrm{NC}_{6} \mathrm{H}_{4}$

1f, $\mathrm{R}=\mathrm{Et}, \mathrm{Ar}=2,4-\mathrm{Cl}_{2} \mathrm{C}_{6} \mathrm{H}_{3}$
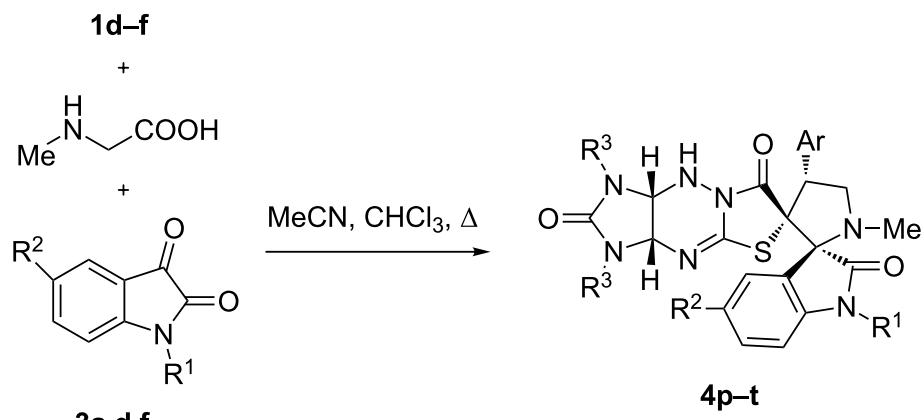

$4 p-t$

3: $R^{2}=H, R^{1}=H(a)$, Allyl (d), $R^{2}=B r, R^{1}=M e(f)$

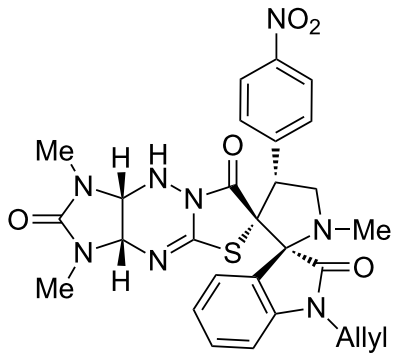

$4 p, 65 \%$

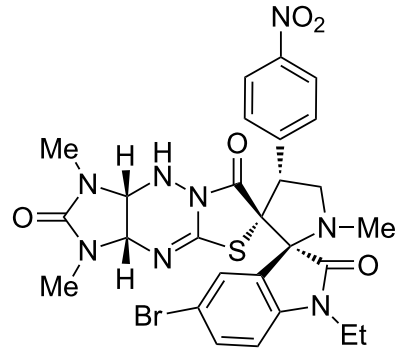

$4 q, 62 \%$

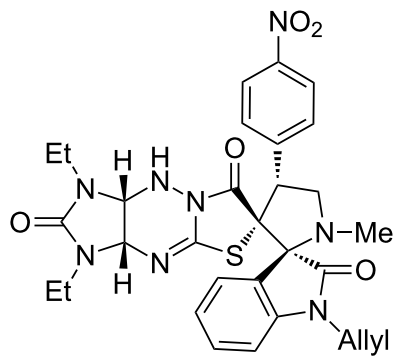

$4 r, 71 \%$

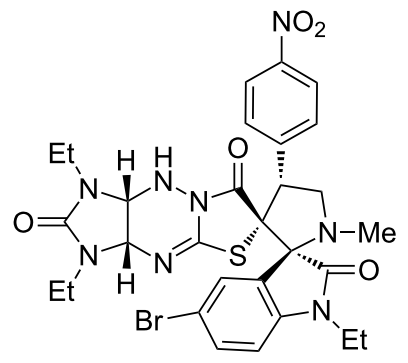

4s, $55 \%$

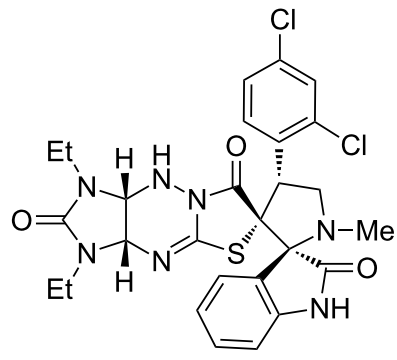

4t, $74 \%$ 
The structures of the synthesized compounds as well as the regioselectivity and diastereoselectivity of the cycloaddition were elucidated by spectroscopic methods and single crystal $\mathrm{X}$-ray diffraction. The cycloadducts $\mathbf{4 a - t}$ were characterized by IR, NMR, and HRMS analytical methods. The IR spectra of compounds 4 showed three intense absorption bands at 1728-1697, 1709-1680 (in some cases instead of these two bands, one broad band is observed), and $1649-1634 \mathrm{~cm}^{-1}$ that are characteristic of oxindole, imidazolidinone, and thiazolidinone ring carbonyl groups. The ${ }^{1} \mathrm{H}$ NMR spectra of compounds 4 exhibited, along with the proton signals of the imidazothiazolotriazine and oxindole moieties, the signals for pyrrolidine ring protons: a singlet at 2.05-2.18 ppm for $\mathrm{N}\left(1^{\prime}\right) \mathrm{Me}$ group protons, two triplets at 3.49-3.66 and 3.93-4.05 ppm assignable to the protons of methylene $\mathrm{C}\left(5^{\prime}\right) \mathrm{H}_{2}$ group, and one triplet at $4.45-4.70 \mathrm{ppm}$ corresponding to the proton of $\mathrm{C}\left(4^{\prime}\right) \mathrm{H}$. This clearly demonstrates the regiochemistry of the cycloaddition. If the other possible regioisomer had formed, the ${ }^{1} \mathrm{H}$ NMR spectra would have shown a singlet for the $\mathrm{C}\left(4^{\prime}\right) \mathrm{H}$ proton.

In more detail, the structure of compounds $\mathbf{4}$ was studied on the example of $\mathbf{4 f}$ by COSY, $\left\{{ }^{1} \mathrm{H}-{ }^{13} \mathrm{C}\right\} \mathrm{HSQC},\left\{{ }^{1} \mathrm{H}-{ }^{13} \mathrm{C}\right\}-$ and $\left\{{ }^{1} \mathrm{H}-{ }^{15} \mathrm{~N}\right\} \mathrm{HMBC}$ NMR experiments. For instance, in the $\left\{{ }^{1} \mathrm{H}-{ }^{13} \mathrm{C}\right\} \mathrm{HMBC}$ spectrum of $\mathbf{4 f}$, the $\mathrm{N}\left(1^{\prime}\right) \mathrm{Me}$ protons (2.17 ppm) correlate with the C-5' (57.52 ppm) and spiro C-2' $(80.29 \mathrm{ppm})$ carbons; the proton of $\mathrm{C}\left(4^{\prime}\right) \mathrm{H}(4.63 \mathrm{ppm})$ of the pyrrolidine ring correlates with the spiro carbon $\mathrm{C}-3$, $(68.47 \mathrm{ppm})$ and the carbon atoms of the $\mathrm{C}\left(5^{\prime}\right) \mathrm{H}_{2}$ and $\mathrm{C}(7)=\mathrm{O}$ $(167.31 \mathrm{ppm})$ groups (Figure 4). The correlations of the $\mathrm{C}\left(5^{\prime}\right) \mathrm{H}_{2}$ group protons are different. One of them (4.02 $\left.\mathrm{ppm}\right)$ shows cross-peaks with a neighboring C-4' carbon atom $(50.90 \mathrm{ppm})$ and the carbon atom of the $\mathrm{N}\left(1^{\prime}\right) \mathrm{Me}(35.38 \mathrm{ppm})$ group. Another one (3.61 ppm), correlates with both spiro carbon atoms C-2' and C-3' (see Supporting Information File 1 for full experimental data).

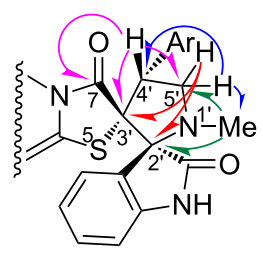

Figure 4: Key interactions in $\left\{{ }^{1} \mathrm{H}^{13} \mathrm{C}\right\} \mathrm{HMBC}$ spectrum of $\mathbf{4 f}$.

Finally, the regio- and stereochemistry of the cycloaddition were confirmed by single crystal X-ray diffraction analysis of compounds 4c (Figure 5), 4e (Figure 6), and 4r (Figure 7) (see Supporting Information Files 2-4). The relative configurations of the stereocenters of compounds 4 are $2^{\prime} R^{*}, 3 \mathrm{a} S^{*}, 3^{\prime} R^{*}, 4^{\prime} R^{*}$, $9 \mathrm{a} R^{*}$.

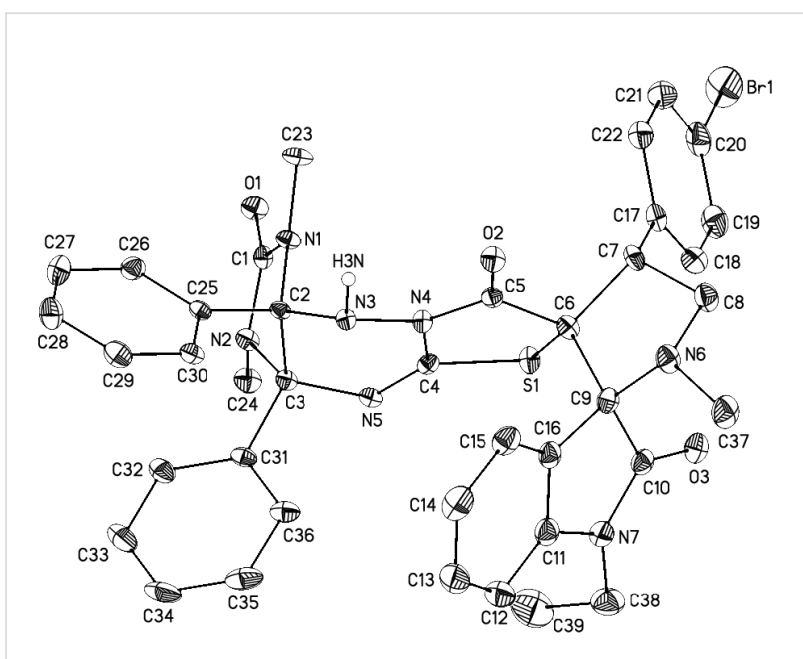

Figure 5: General view of $\mathbf{4 c}$ in the crystal in thermal ellipsoids representation ( $50 \%$ probability). Hydrogen atoms connected to carbon atoms are omitted for clarity.

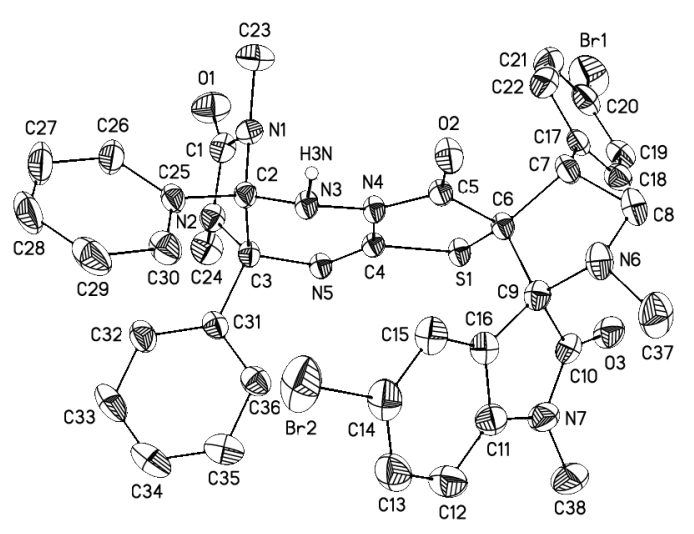

Figure 6: General view of $4 \mathrm{e}$ in the crystal in thermal ellipsoids representation ( $40 \%$ probability). Hydrogen atoms connected to carbon atoms are omitted for clarity.

The homogeneity of compounds $\mathbf{4} \mathbf{b}-\mathbf{d}, \mathbf{f}-\mathbf{i}, \mathbf{l}-\mathbf{n}$ was additionally confirmed by powder X-ray diffraction. The analysis of the experimental powder diffraction patterns of compounds $\mathbf{4 b}-\mathbf{d}, \mathbf{f}-\mathbf{i}, \mathbf{l}-\mathbf{n}$ show that the investigated samples were single phase (see Supporting Information File 1). Thus, the cycloaddition of azomethine ylides was found to be highly regioselective, as the electron-rich carbon of the dipole adds to the $\beta$-carbon of the $\alpha, \beta$-unsaturated moiety of dipolarophile 1 . Further the reaction is diastereoselective, as only one diastereomer is obtained in good to high yields, although multiple (five) stereocenters are present in products 4 . 


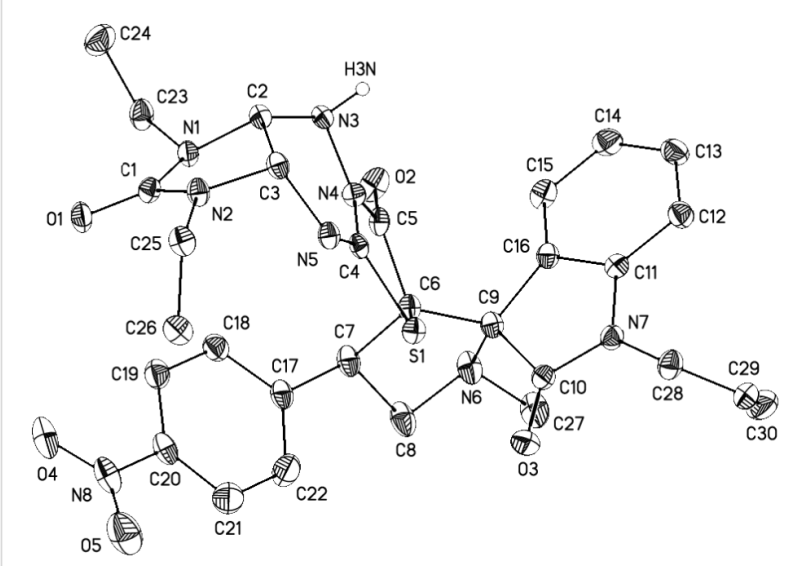

Figure 7: General view of $\mathbf{4 r}$ in the crystal in thermal ellipsoids representation ( $50 \%$ probability). Hydrogen atoms connected to carbon atoms are omitted for clarity.
The possible approaches of the azomethine ylide are shown in Figure 8. The X-ray diffraction structures of $\mathbf{4 c}, \mathbf{4 e}$, and $\mathbf{4 r}$ reflect that the cycloaddition proceeds via an exo-transition state, because the corresponding endo-transition state would require more energy of activation, as it would result in an electrostatic repulsion between the cis carbonyls thus increasing the free energy of activation [46,47]. As expected, the azomethine ylide adds at the double bond of $\mathbf{1 a - c}$ from that side in which the phenyl substituents are directed (anti-exo).

\section{Conclusion}

In summary, a simple, general, and efficient one-pot method for the construction of previously unknown substituted dispiro[imidazo[4,5-e]thiazolo[3,2-b]-1,2,4-triazine-6,3'-pyrrolidine-2',3"-indoles] was developed. This method is based on the highly regio- and diastereoselective 1,3-dipolar cycloaddition reaction of azomethine ylides generated in situ from various isatin derivatives and sarcosine to readily available 6-benzyli-

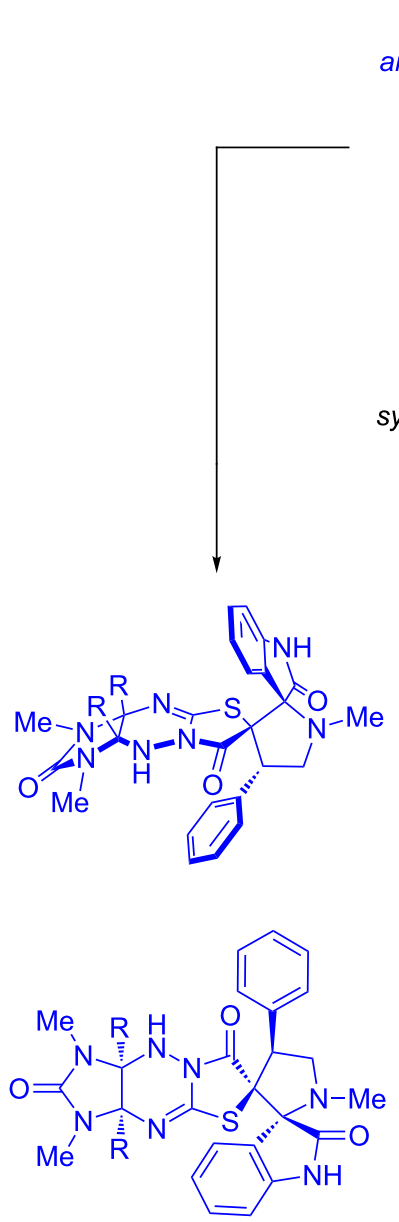

anti-exo
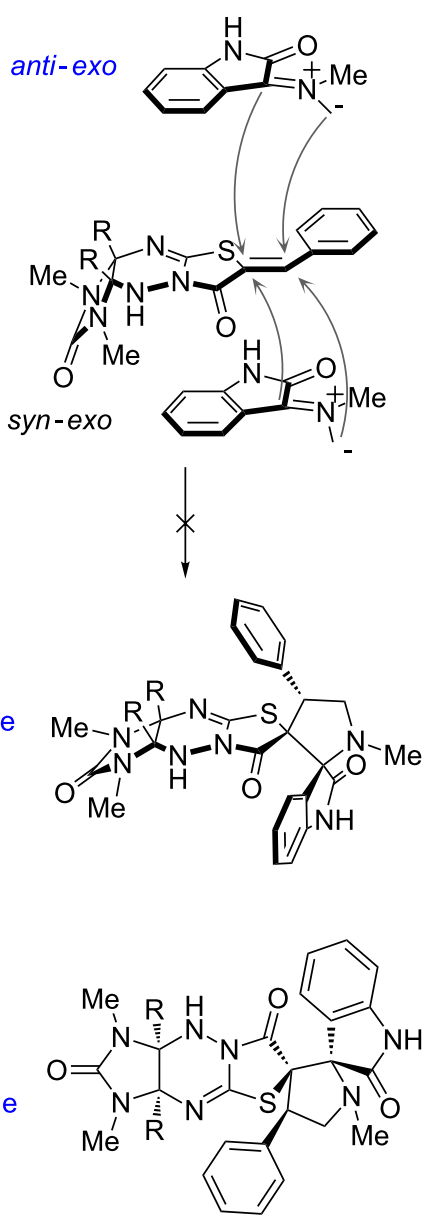

syn-exo
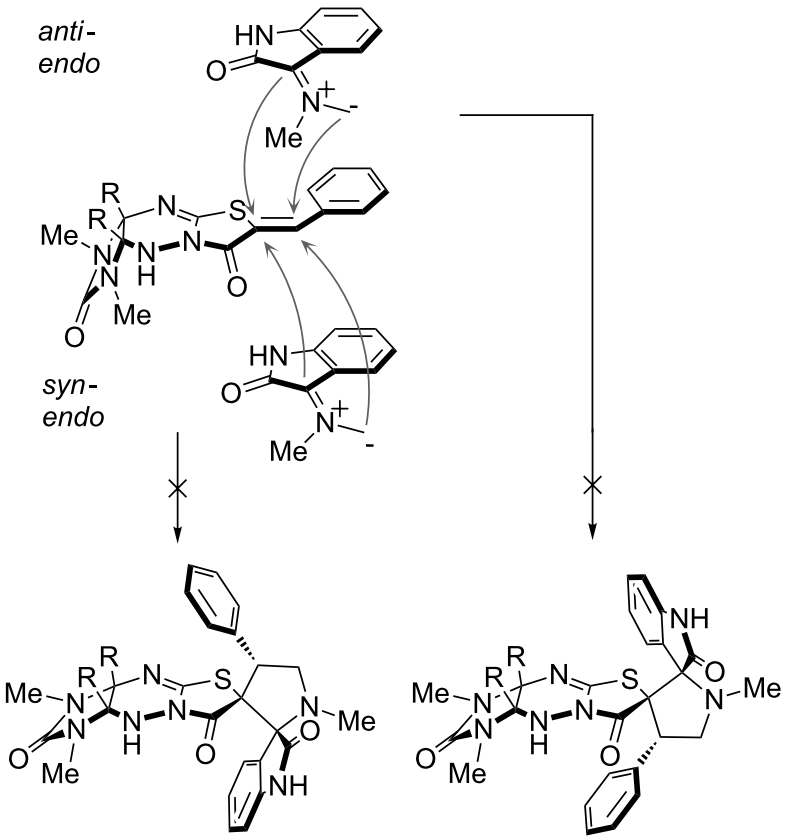

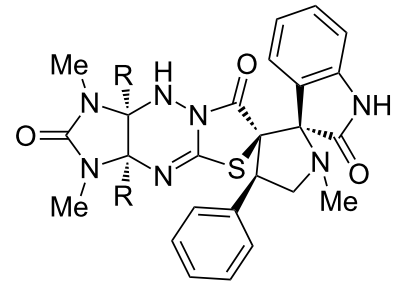

syn-endo

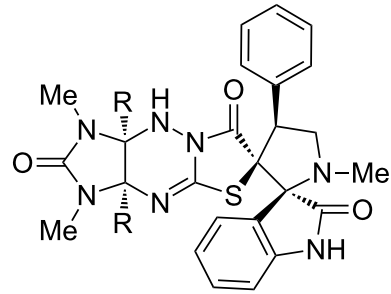

anti-endo 
deneimidazo[4,5-e]thiazolo[3,2-b]-1,2,4-triazine-2,7-diones. The synthesized structures represent a new class of promising bioactive polynuclear dispiroheterocyclic structures comprising pyrrolidinyloxindole and imidazothiazolotriazine moieties. Investigations of cytotoxic activities of the synthesized products against A549, HCT116, RD, and MCF7 cell lines are in progress.

\section{Supporting Information}

\section{Supporting Information File 1}

Experimental and analytical data.

[http://www.beilstein-journals.org/bjoc/content/

supplementary/1860-5397-12-216-S1.pdf]

\section{Supporting Information File 2}

CIF file for compound $\mathbf{4 c}$.

[http://www.beilstein-journals.org/bjoc/content/

supplementary/1860-5397-12-216-S2.cif]

\section{Supporting Information File 3}

CIF file for compound $\mathbf{4 e .}$

[http://www.beilstein-journals.org/bjoc/content/ supplementary/1860-5397-12-216-S3.cif]

\section{Supporting Information File 4}

CIF file for compound $\mathbf{4 r}$.

[http://www.beilstein-journals.org/bjoc/content/ supplementary/1860-5397-12-216-S4.cif]

\section{Acknowledgements}

This work was supported by the Russian Science Foundation (Project No 14-50-00126).

\section{References}

1. Ananikov, V. P.; Khemchyan, L. L.; Ivanova, Yu. V.; Bukhtiyarov, V. I.; Sorokin, A. M.; Prosvirin, I. P.; Vatsadze, S. Z.; Medved'ko, A. V.; Nuriev, V. N.; Dilman, A. D.; Levin, V. V.; Koptyug, I. V.; Kovtunov, K. V.; Zhivonitko, V. V.; Likholobov, V. A.; Romanenko, A. V.; Simonov, P. A.; Nenajdenko, V. G.; Shmatova, O. I.; Muzalevskiy, V. M.; Nechaev, M. S.; Asachenko, A. F.; Morozov, O. S.; Dzhevakov, P. B.; Osipov, S. N.; Vorobyeva, D. V.; Topchiy, M. A.; Zotova, M. A.; Ponomarenko, S. A.; Borshchev, O. V.; Luponosov, Yu. N.; Rempel, A. A.; Valeeva, A. A.; Stakheev, A. Yu.; Turova, O. V.; Mashkovsky, I. S.; Sysolyatin, S. V.; Malykhin, V. V.; Bukhtiyarova, G. A.; Terent'ev, A. O.; Krylov, I. B. Russ. Chem. Rev. 2014, 83, 885-985. doi:10.1070/RC2014v83n10ABEH004471

2. Narayan, R.; Potowski, M.; Jia, Z.-J.; Antonchick, A. P.; Waldmann, H. Acc. Chem. Res. 2014, 47, 1296-1310. doi:10.1021/ar400286b
3. Borad, M. A.; Bhoi, M. N.; Prajapati, N. P.; Patel, H. D. Synth. Commun. 2014, 44, 1043-1057. doi:10.1080/00397911.2013.858361

4. Kissane, M.; Maguire, A. R. Chem. Soc. Rev. 2010, 39, 845-883. doi:10.1039/B909358N

5. Gazieva, G. A.; Kolotyrkina, N. G.; Kravchenko, A. N.; Makhova, N. N. Russ. Chem. Bull. 2014, 63, 431-434. doi:10.1007/s11172-014-0449-2

6. Sosnovskikh, V. Y.; Kornev, M. Y.; Moshkin, V. S.; Buev, E. M. Tetrahedron 2014, 70, 9253-9261. doi:10.1016/j.tet.2014.09.090

7. Najera, C.; Sansano, J. M. Curr. Org. Chem. 2003, 7, 1105-1150. doi:10.2174/1385272033486594

8. Bharitkar, Y. P.; Kanhar, S.; Suneel, N.; Mondal, S. K.; Hazra, A.; Mondal, N. B. Mol. Diversity 2015, 19, 251-261. doi:10.1007/s11030-015-9574-6

9. Tietze, L. F.; Brasche, G.; Gericke, K. M. Domino Reactions in Organic Synthesis; Wiley-VCH: Weinheim, 2006. doi:10.1002/9783527609925

10. Liu, Y.; Wang, H.; Wan, J. Asian J. Org. Chem. 2013, 2, 374-386. doi:10.1002/ajoc.201200180

11. Borad, M. A.; Bhoi, M. N.; Prajapati, N. P.; Patel, H. D. Synth. Commun. 2014, 44, 897-922. doi:10.1080/00397911.2013.843196

12. Sun, J.; Chen, L.; Gong, H.; Yan, C.-G. Org. Biomol. Chem. 2015, 13, 5905-5917. doi:10.1039/C5OB00437C

13. Karnakar, K.; Ramesh, K.; Reddy, K. H. V.; Anil Kumar, B. S. P.; Nanubonula, J. B.; Nageswar, Y. V. D. New J. Chem. 2015, 39, 8978-8983. doi:10.1039/C5NJ01448D

14. Xia, M.; Ma, R.-Z. J. Heterocycl. Chem. 2014, 51, 539-554. doi:10.1002/jhet.1114

15. Singh, G. S.; Desta, Z. Y. Chem. Rev. 2012, 112, 6104-6155. doi:10.1021/cr300135y

16. Antonchick, A. P.; Gerding-Reimers, C.; Catarinella, M.; Schürmann, M.; Preut, H.; Ziegler, S.; Rauh, D.; Waldmann, H. Nat. Chem. 2010, 2, 735-740. doi:10.1038/nchem.730

17. Wang, C.-S.; Zhu, R.-Y.; Zheng, J.; Shi, F.; Tu, S.-J. J. Org. Chem. 2015, 80, 512-520. doi:10.1021/jo502516e

18. Pavlovska, T. L.; Redkin, R. G.; Lipson, V. V.; Atamanuk, D. V. Mol. Diversity 2016, 20, 299-344. doi:10.1007/s11030-015-9629-8

19. Marti, C.; Carreira, E. M. Eur. J. Org. Chem. 2003, 2209-2219. doi:10.1002/ejoc. 200300050

20. Galliford, C. V.; Scheidt, K. A. Angew. Chem., Int. Ed. 2007, 46, 8748-8758. doi:10.1002/anie.200701342

21. Pardasani, P.; Pardasani, R. T.; Chaturvedi, V.; Saxena, A. Indian J. Chem., Sect. B: Org. Chem. Incl. Med. Chem. 2003, 42B, $412-415$.

22. Yu, B.; Yu, D.-Q.; Liu, H.-M. Eur. J. Med. Chem. 2015, 97, 673-698. doi:10.1016/j.ejmech.2014.06.056

23. Tan, W.; Zhu, X.-T.; Zhang, S.; Xing, G.-J.; Zhu, R.-Y.; Shi, F. RSC Adv. 2013, 3, 10875-10886. doi:10.1039/c3ra40874d

24. Dong, H.; Song, S.; Li, J.; Xu, C.; Zhang, H.; Ouyang, L. Bioorg. Med. Chem. Lett. 2015, 25, 3585-3591. doi:10.1016/j.bmcl.2015.06.076

25. Kaur, A.; Singh, B.; Vyas, B.; Silakari, O. Eur. J. Med. Chem. 2014, 79, 282-289. doi:10.1016/j.ejmech.2014.04.022

26. Poornachandran, M.; Raghunathan, R. Tetrahedron 2006, 62, 11274-11281. doi:10.1016/j.tet.2006.09.008

27. Karthikeyan, K.; Sivakumar, P. M.; Doble, M.; Perumal, P. T. Eur. J. Med. Chem. 2010, 45, 3446-3452. doi:10.1016/j.ejmech.2010.04.035

28. Li, X.; Liu, B.; Liu, H.; Yu, X.; Yi, P. J. Heterocycl. Chem. 2012, 49 , 1050-1053. doi:10.1002/jhet.925 
29. Chandraprakash, K.; Sankaran, M.; Uvarani, C.; Shankar, R.; Ata, A.; Dallemer, F.; Mohan, P. S. Tetrahedron Lett. 2013, 54, 3896-3901. doi:10.1016/j.tetlet.2013.05.077

30. Ivanenkov, Y. A.; Vasilevski, S. V.; Beloglazkina, E. K.; Kukushkin, M. E.; Machulkin, A. E.; Veselov, M. S.; Chufarova, N. V.; Chernyaginab, E. S.; Vanzcool, A. S.; Zyk, N. V.; Skvortsov, D. A.; Khutornenko, A. A.; Rusanov, A. L.; Tonevitsky, A. G.; Dontsova, O. A.; Majouga, A. G. Bioorg. Med. Chem. Lett. 2015, 25, 404-409. doi:10.1016/j.bmcl.2014.09.070

31. Anis'kov, A. A.; Kamneva, I. Ye.; Zheleznova, M. A.; Yegorova, A. Yu. Chem. Heterocycl. Compd. 2015, 51, 709-712. doi:10.1007/s10593-015-1763-9

32. Kurbatov, S. V.; Zarubaev, V. V.; Karpinskaya, L. A.; Shvets, A. A.; Kletsky, M. E.; Burov, O. N.; Morozov, P. G.; Kiselev, O. I.; Minkin, V. I. Russ. Chem. Bull. 2014, 63, 1130-1136. doi:10.1007/s11172-014-0560-4

33. Ruanpanun, P.; Laatsch, H.; Tangchitsomkid, N.; Lumyong, S. World J. Microbiol. Biotechnol. 2011, 27, 1373-1380. doi:10.1007/s11274-010-0588-z

34. Nagamatsu, T.; Yamasaki, H.; Hirota, T.; Yamato, M.; Kido, Y.; Shibata, M.; Yoneda, F. Chem. Pharm. Bull. 1993, 41, 362-368. doi:10.1248/cpb.41.362

35. Kiselev, O. I.; Deyeva, E. G.; Melnicova, T. I.; Kozeletskaia, K. N.; Kiselev, A. S.; Rusinov, V. L.; Charushin, V. N.; Chupahin, O. N. Vopr. Virusol. 2012, 57, 9-12.

36. Abdel-Rahman, R. M.; Seada, M.; Fawzy, M.; El-Baz, I. Pharmazie 1994, 49, 729-733.

37. Abdel-Rahman, R. M.; Seada, M.; Fawzy, M.; El-Baz, I. Boll. Chim. Farm. 1994, 133, 381-388.

38. Abd El-Moneim, M.; Hasanen, J. A.; El-Deen, I. M.; Abd El-Fattah, W. Res. Chem. Intermed. 2015, 41, 3543-3561. doi:10.1007/s11164-013-1470-z

39. El-Nassan, H. B. Eur. J. Med. Chem. 2012, 53, 22-27. doi:10.1016/j.ejmech.2012.03.028

40. Abraham, S.; Hadd, M. J.; Tran, L.; Vickers, T.; Sindac, J.; Milanov, Z. V.; Holladay, M. W.; Bhagwat, S. S.; Hua, H.; Ford Pulido, J. M.; Cramer, M. D.; Gitnick, D.; James, J.; Dao, A.; Belli, B.; Armstrong, R. C.; Treiber, D. K.; Liu, G. Bioorg. Med. Chem. Lett. 2011, 21, 5296-5300. doi:10.1016/j.bmcl.2011.07.027

41. Gazieva, G. A.; Serkov, S. A.; Sigai, N. V.; Kostikova, N. N.; Nelyubina, Yu. V.; Shishkova, E. A.; Kravchenko, A. N. Chem. Heterocycl. Compd. 2013, 49, 1097-1101. doi:10.1007/s10593-013-1349-3

42. Neville, R. J. Org. Chem. 1958, 23, 1588-1590. doi:10.1021/jo01104a630

43. Sigachev, A. S.; Kravchenko, A. N.; Lyssenko, K. A.; Belyakov, P. A.; Lebedev, O. V.; Makhova, N. N. Mendeleev Commun. 2003, 13, 190-191. doi:10.1070/MC2003v013n04ABEH001810

44. Gazieva, G. A.; Poluboyarov, P. A.; Nelyubina, Yu. V.; Struchkova, M. I.; Kravchenko, A. N. Chem. Heterocycl. Compd. 2012, 48, 1382-1389. doi:10.1007/s10593-012-1147-3

45. Gazieva, G. A.; Poluboyarov, P. A.; Popov, L. D.; Kolotyrkina, N. G.; Kravchenko, A. N.; Makhova, N. N. Synthesis 2012, 44, 3366-3370. doi:10.1055/s-0032-1317194

46. He, J.; Ouyang, G.; Yuan, Z.; Tong, R.; Shi, J.; Ouyang, L. Molecules 2013, 18, 5142-5154. doi:10.3390/molecules 18055142

47. Kumar, R. R.; Perumal, S.; Senthilkumar, P.; Yogeeswari, P.; Sriram, D. Tetrahedron 2008, 64, 2962-2971. doi:10.1016/j.tet.2008.01.072

\section{License and Terms}

This is an Open Access article under the terms of the Creative Commons Attribution License (http://creativecommons.org/licenses/by/4.0), which permits unrestricted use, distribution, and reproduction in any medium, provided the original work is properly cited.

The license is subject to the Beilstein Journal of Organic Chemistry terms and conditions: (http://www.beilstein-journals.org/bjoc)

The definitive version of this article is the electronic one which can be found at: doi:10.3762/bjoc. 12.216 